\title{
Correction to: perspectives on medical education meta- research special issue: a call for papers exploring how research is performed, communicated, verified and rewarded
}

\author{
Lauren A. Maggio - Stefanie Haustein (D) - Anthony R. Artino Jr (D)
}

Published online: 14 December 2020

(C) The Author(s) 2020

\section{Correction to:} Perspect Med Educ 2020

https://doi.org/10.1007/s40037-020-00627-8

The original version of this article unfortunately contained a mistake. References [1, 2] and [4] were incorrect. The corrected references are given below. The original article has been corrected.

Open Access This article is licensed under a Creative Commons Attribution 4.0 International License, which permits use, sharing, adaptation, distribution and reproduction in any medium or format, as long as you give appropriate credit to the original author(s) and the source, provide a link to the Creative Commons licence, and indicate if changes were made. The images or other third party material in this article are included in the article's Creative Commons licence, unless indicated otherwise in a credit line to the material. If material is not included in the article's Creative Commons licence and your intended use is not permitted by statutory regulation or exceeds the permitted use, you will need to obtain permission directly from the copyright holder. To view a copy of this licence, visit http://creativecommons.org/licenses/by/4.0/.

The views expressed in this article are those of the authors and do not necessarily reflect the official policy or position of the Uniformed Services University of the Health Science, the U.S. Department of Defense, or the U.S. Government.

The online version of the original article can be found under https://doi.org/10.1007/s40037-020-00627-8.

L. A. Maggio $(\bowtie)$

Uniformed Services University of the Health Sciences,

Bethesda, MD, USA

lauren.maggio@usuhs.edu

S. Haustein

University of Ottawa, Ottawa, ON, Canada

A. R. Artino

School of Medicine and Health Sciences, The George

Washington University, Washington, DC, USA

\section{References}

1. Ioannidis JP, Fanelli D, Dunne DD, Goodman SN. Meta-research: Evaluation and improvement of research methods and practices. PLoS Biol. 2015;13:e1002264.

2. Ioannidis JP. Meta-research: Why research on research matters. PLoS Biol. 2018;16:e2005468.

4. Maggio LA, Artino AR, Driessen EW. Preprints: Facilitating early discovery, access, and feedback. Perspect Med Educ. 2018;7:287-9. 